\title{
INTEGRATION OF PEDAGOGY INTO TECHNOLOGY: A PRACTICAL PARADIGM
}

\author{
Zahra Hosseini ${ }^{1}$, \& Jani Kinnunen ${ }^{2}$ \\ ${ }^{1}$ Information Technology and Communication, Tampere University (Finland) \\ ${ }^{2}$ Information Systems, Abo Akademi (Finland)
}

\begin{abstract}
Technology, with its rapid growth and vast impacts on all areas of human life, has increased well-being and facilitated daily tasks in our private life as well as in business and marketing, medical and healthcare services, and education. The global Covid-19 pandemic has shown the importance of Internet and technology to keep businesses running and reduce the problems emerging from social distancing and even saving lives through healthcare systems; likewise, educational systems speeded their technological facilities to run and develop normal educational activities. Although many studies had already acknowledged the necessity of using technology in education, the lack of facilities and knowledge of using technology in educational systems was reported in the beginning of the pandemic. The pandemic pushed educational systems to integrate technology into pedagogy by facilitating information transfer and communication. However, the challenge of enhancing the quality of information is still prevalent. This paper focuses on a bilateral necessity of integration of pedagogy and technology: while the potential of technology in educational systems is widely acknowledged, the practical usage of learning theories and pedagogical principles in designing digital services is far from a completed mission. Many user-experience (UX) studies determine technological, behavioral, social, and motivational factors to promote user-centric design to enhance the quality of content, while limited attention is given to pedagogical factors. We introduce integration of pedagogy into technology as a new paradigm in user-centric design, not only in the educational system but also in a general context. Mishra and Koehler (2006) introduced integration of technology into pedagogy (TP) through the Technological Pedagogical Content (TPACK) framework as required knowledge for teachers. This paper employs the TP concept in a broader context of Technological Pedagogical Content Design (TPCD), which utilizes the pedagogical element in the user-experience based practice to develop a user-centric design approach.
\end{abstract}

Keywords: Technology integration, TPACK, TPCD, user experience, user-centric design.

\section{Introduction}

Rapidly developing technology, adoption to ever broader areas, and increasing usage has had impressive effects on our lives and increased the quality of our lifestyle as well as on the areas of business and marketing (Grewal, 2020), medical and health care industry (Hussien et al., 2021; Nomani \& Hussain, 2020) and education (Cloete, 2017; Budhwar, 2017). The global Covid-19 pandemic has demonstrated the importance of Internet and technology to save lives and reduce the problems that were emerging from social distancing. (Ting et al., 2020; Singh et al., 2020). Similarly, educational systems speeded their technological facilities to return to normal activities. Technology-supported education with different aspects and affordances have concerned online education, e-learning, blended learning, web-based education, virtual education, or IT-supported teaching. Further, Internet and different tools and software are facilitating teaching and learning in pandemic conditions (Ionescu et al., 2020; Hoq, 2020, Kinnunen \& Georgescu, 2020). Using different apps and online meetings improve digital literacy, enhance the use of soft copy of materials, encourage students to be self-learners, improve collaboration, and give attention toward using electronic facilities for education (Jena, 2020). In addition, Learning Management System (LMS) that was already available received more attention during the lockdown period; however, at starting a pandemic, the lack of facilities and knowledge of using technology in educational systems was reported in many countries. Onyema et al. (2020), after collecting data from 200 respondents including policymakers, parents, teachers, and students in different countries, found how the pandemic had pushed educators and students to rely on technology to continue education, while problems arose from poor infrastructures of network, power, inaccessibility issues, or poor digital skills ed. The pandemic pushes educational systems to facilitate information transfer and communication, however, the still prevailing challenge of enhancing the quality of information cannot be over-emphasized. 


\section{The current phase of the bidirectional integration}

\subsection{Integrating technology into pedagogy}

Integrating technology into pedagogy is a suggested approach to enhance the quality of using technology for teaching and learning. Technology integration is promising in increasing the meaningfulness of the use of a device or a tool (Hyndman, 2018) for students' engagement as the best teaching practice (Hechter et al., 2012). The concept of technology integration has drawn educators' attention by Morton's (1996)'s claim that using technology does not mean just using a computer as an add-on or a tool for teaching and learning. Accordingly, many researchers followed by developing the concept of technology integration defined as integrating technology affordances into teaching (in the classroom or educational environments) for educational purposes and extended it through theories, frameworks, and models. In the last two decades, many scholars have presented different approaches for integrating technology into teaching. Some of recent technology integration models include Substitution, Augmentation, Modification and Redefinition (SAMR), Level of Teaching Innovation (LOTI), Technology Integration Matrix (TIM), Triple E framework (Extend, Enhance and Engage), and Technological Pedagogical Content Knowledge (TPACK) (Arora \& Chander, 2020). Each model has shown its potential in under specific conditions. With a critical and analytical view, Shirley (2018) listed the issues and barriers of integrating technology into teaching, concluding that technology cannot replace a teacher; however, pandemic restrictions have increased the necessity of technology integration more than ever, and the knowledge about technology integration has become critical in education.

\subsection{Integrating pedagogy into technology}

When the concept of technology integration is under discussion, mostly only the integration of technology into teaching is considered, e.g. within the framework of Technological Pedagogical Content Knowledge (TPACK), one of the most popular models for integrating technology into teaching. Technological Pedagogical Content (TPC) is an intersection of technology, pedagogy and content that provides special knowledge of technology to make difficult concepts easier to learn. This knowledge requires a deep understanding of the representation of concepts using technological and pedagogical techniques (Mishra \& Koehler, 2006). TPACK is widely known by scholars and administrators and it is discussed in numerous studies (Hosseini 2015a, 2015b, 2016; Sintawati \& Abdurrahman, 2020; Wijaya, 2020). Nevertheless, utilizing the TPACK framework for integrating pedagogy into technology, in order to design digital services, is a new paradigm. Human-computer Interaction (HCI) with respect to behavioral science and User Experience (UX) methods has already attempted to enhance the quality of digital services and products (Hassenzahl, 2013; Mtebe, 2019; Semerádová \& Weinlich, 2020). While HCI researchers utilize technological, behavioral, social, and motivational factors to promote user-centric design to enhance the quality of content, less attention is paid to pedagogical factors in designing. It seems evident that pedagogical principles get a place only when the purpose relates to designing an educational environment. Hence, this study attempts to introduce the potential of integrating pedagogy into technology also in a broader context of non-educational areas such as online digital design of, e.g. websites of corporations or government organizations.

\section{Method}

Our aim is to draw attention to a bilateral necessity of integration of pedagogy and technology and propose the practical model and provide instructions on how to use pedagogical principles not only in the educational environment but also in a broader context of the modern digital society. Therefore, to elaborate the new paradigm, we undertake a design research study in line with the definition: "Design research involves an investigation of strategies, procedures, methods, routes, tactics, schemes, and modes through which people work creatively. Design involves the testing of ideas, materials, and technologies. It involves innovative conceptual development, product evolution, and market modification. It also involves research into cultural, social, economic, aesthetic and ethical issues" (Roggema, 2017. p. 2).

We introduce integration of pedagogy into technology as a new paradigm of a user-centric design in a general context. Accordingly, we construct and introduce the Technological Pedagogical Content Design (TPCD) model as a practical design extension of Technological Pedagogical Content Knowledge (TPCK) with more focus on integrating pedagogy into technology than integrating technology into teaching and learning. The purpose is to take up the challenge presented by Don Norman as quoted by Hassenzahl (2013): "Design has moved from its origins of making things look attractive (styling) to making things that fulfill true needs in an effective understandable way (design_studies and interactive design) to the enabling of experiences (experience design). Each step is more difficult than the one before each requires and builds upon what was learned before". 


\section{Integrating pedagogy into technology as a design model (TPCD)}

Mishra and Koehler (2006) were the first to introduce integration of technology to pedagogy (TP) through the Technological Pedagogical Content (TPACK) framework as the required knowledge for teachers. This paper employs the TP concept in a broader context to create the new model of Technological Pedagogical Content Design (TPCD). It utilizes the pedagogical element in the user-experience practice to develop a user-centric design approach. TPCD is a model to integrate pedagogy to the technology in designing digital services (e.g. websites). Based on TPCD, users are self-learners, who are after some information transferred and learned through digital services. TPCD is a potential model not only to define the criteria for evaluating a design but also to offer systematic instructions to design. TPC is the core of design and defined as the integration of the three fundamental facts: (a) technology that includes different available technology to create and design; (b) pedagogy, which is mostly related to learning theories and knowledge about learners (users); and (c) content that defines the construct of each subject that can be linear on nonlinear. There are three sub-integrations of TPC including Pedagogical Content (PC), Technological Content (TC), and Technological Pedagogy (TP) as described in Figure 1.

Figure 1. Technological Pedagogical Content Design (TPCD).

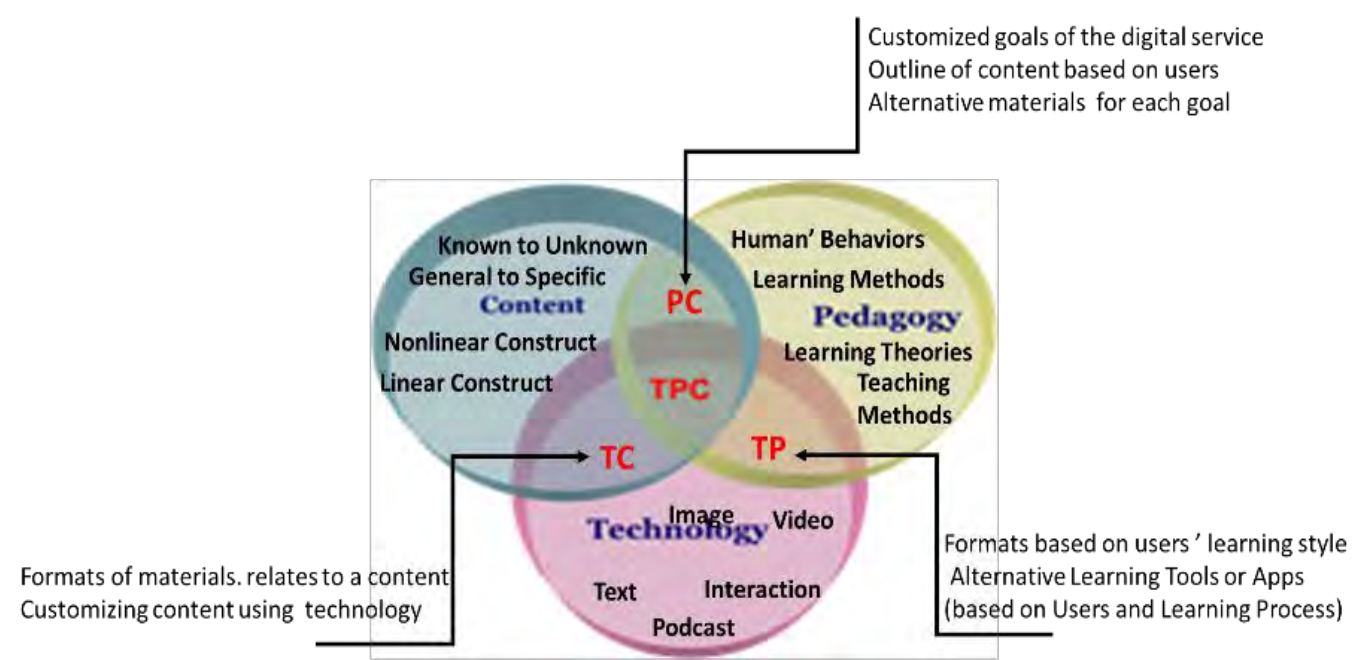

The TPCD utilizes a user-experience method for collecting data from users. The literature has shown the potential of user-experience methods as behavioral science to design technology (Hassenzahl, 2013; Mtebe, 2019; Semerádová \& Weinlich, 2020). However, considering the pedagogical aspect of users (e.g. their learning style) is suggested to lead to a new practical paradigm. Designing the content based on increasing attractiveness is assumed an important criterion for a successful design and regarding some method (e.g. teaching method) for organizing the outline of the content may increase the easiness of use and findability of content for users (PC).

Using technology tools and environments for delivering content (TC) is usually a familiar skill for designers but looking at the users as learners to integrate pedagogy into technological content (TPC or PTC) is a new challenging task to increase the user satisfaction. Another application example of a non-educational environment is organizing peer-learning or collaborative-learning options as a part of designing a game to increase the satisfaction of gamers. Further, considering the diversity of learning styles for selecting materials or predicting the paths of a user to read or learn information from a website may increase the findability and usability of information on the pages of a website.

This paper describes the integration of pedagogy into technology design without a direct educational purpose. At the level of design, components of TPC are clarified. Each level includes syllables of concepts, which helps the designer ensure the integration. To fulfil each task, selected key questions are suggested in Table 1. These questions can be obtained through exaction methods. It is notable that concepts and questions may vary based on the design case of a digital service (e.g. website). 
Table 1. The systematic instruction to design based on TPCD.

\begin{tabular}{|c|c|c|c|}
\hline Level & Concepts & Key questions / issues & Execution methods \\
\hline \multirow[t]{2}{*}{$\begin{array}{l}\text { Pedagogical } \\
\text { Analysis }\end{array}$} & $\begin{array}{l}\text { Aim of the digital } \\
\text { service }\end{array}$ & $\begin{array}{l}\text { Why is this service required? } \\
\text { What the digital service aims to offer? }\end{array}$ & $\begin{array}{l}\text { Interviews with digital } \\
\text { service creators }\end{array}$ \\
\hline & $\begin{array}{l}\text { Overlapping the aim of } \\
\text { digital service and } \\
\text { users }\end{array}$ & How the aim is customized and compromised? & Discussion \\
\hline $\begin{array}{l}\text { Pedagogical } \\
\text { Content }\end{array}$ & $\begin{array}{l}\text { Content sequence } \\
\text { Learning styles } \\
\text { Learning theories } \\
\text { Teaching and learning } \\
\text { methods }\end{array}$ & $\begin{array}{l}\text { What is the consequence of content (linear or } \\
\text { non-linear)? } \\
\text { How a user gets content easier or faster? } \\
\text { What is the conceptual map of the content? } \\
\text { What are activities to transfer the content } \\
\text { (constructivism or direct education)? }\end{array}$ & $\begin{array}{l}\text { Preparing content outlines' } \\
\text { sequences } \\
\text { Alternative methods and } \\
\text { materials to gain a particular } \\
\text { goal }\end{array}$ \\
\hline $\begin{array}{l}\text { Pedagogical } \\
\text { Technology }\end{array}$ & $\begin{array}{l}\text { Peer learning or } \\
\text { collaborative tools } \\
\text { Learning tools } \\
\text { Learning theories in } \\
\text { visualization or } \\
\text { textualization }\end{array}$ & $\begin{array}{l}\text { What activity users do to reach the goal } \\
\text { (reading, listening, game, etc.)? } \\
\text { In which ways technology helps users } \\
\text { understand and reach their purposed } \\
\text { destination easier, faster and more effectively? }\end{array}$ & $\begin{array}{l}\text { Using principles } \\
\text { (e.g. Gestalt in designing) } \\
\text { Formats based on users' } \\
\text { learning style } \\
\text { Aural, visual, verbal, logical } \\
\text { and ...learning }\end{array}$ \\
\hline $\begin{array}{l}\text { Technological } \\
\text { Pedagogical } \\
\text { Content }\end{array}$ & Scaffolding the design & $\begin{array}{l}\text { How easily users move on, get to destination, } \\
\text { and receive satisfaction? }\end{array}$ & $\begin{array}{l}\text { alignment of elements and its } \\
\text { consistency }\end{array}$ \\
\hline
\end{tabular}

\section{Conclusions}

Technology has revolutionized life in modern digital societies as part of all aspects of human life. The constant development of technologies makes their optimal usage a challenging task. This challenge is taken by design science. Its role has been evolving from user-friendly design towards user-centric design. Conclusively, this paper suggested using pedagogy to design technology in non-educational domains (such as games and websites, for instance) to enhance the quality of digital services in a society. Interdisciplinary knowledge is required to understand the diversity of users and designing team members in different application areas. The rapid development and increasing use of technology have forced the design process to become more dynamic and complex. However, this should not discourage the researchers, companies, and designers to define the instructions to guide building digital services. This paper introduced the general model for integrating pedagogy into technology as a new paradigm and suggested practical instructions for designing technology based on pedagogical integration (Table 1). TPCD is still taking its first steps to become an established model; the authors have implemented it to redesign a soon-published English-language part of a business association website (Suomen Yrittäjät) in Finland (Hosseini et al., unpublished).

\section{References}

Arora, C., \& Chander, S. (2020). Integrating Technology into Classroom Learning. Indian Journal of Educational Technology, 2(1), 84-105.

Budhwar, K. (2017). The role of technology in education. International Journal of Engineering Applied Sciences and Technology, 2(8), 55-57.

Cloete, A. L. (2017). Technology and education: Challenges and opportunities. HTS Theological Studies, 73(4), 1-7.

Grewal, D., Hulland, J., Kopalle, P. K., \& Karahanna, E. (2020). The future of technology and marketing: a multidisciplinary perspective. Journal of the Academy of Marketing Science volume, 48, 1-8.

Hassenzahl, M. (2013). User experience and experience design. The Encyclopedia of Human-Computer Interaction. Retrieved April 27, 2021, from: https://www.interactiondesign.org/literature/book/the-encyclopedia-of-human-computer-interaction-2nd-ed/userexperience-and-experience-design 
Hechter, R. P., Phyfe, L. D., \& Vermette, L. A. (2012). Integrating technology in education: Moving the TPCK framework towards practical applications. Education Research and Perspectives, 39, $136-152$.

Hoq, M. Z. (2020). E-Learning during the period of pandemic (COVID-19) in the kingdom of Saudi Arabia: an empirical study. American Journal of Educational Research, 8(7), 457-464.

Hosseini, Z. (2015a). Development of technological pedagogical content knowledge through constructionist activities. Procedia-Social and Behavioral Sciences, 182, 98-103. doi:10.1016/j.sbspro.2015.04.743

Hosseini, Z. (2015b). The Usage of Constructivism to Enhance Technology Integration Knowledge. Technology of Education Journal (TEJ), 10(1), 65-74. doi:10.22061/TEJ.2015.439

Hosseini, Z. (2016). The Comparison between the Effect of Constructivism and Directed Instruction on Student Teachers' Technology Integration. New Educational Approach. Journal of University of Isfahan, 10(2), 21-40. Retrieved April 27, 2021, from: https://www.sid.ir/en/journal/ViewPaper.aspx?id=574895

Hosseini, Z. Hytönen, K., \& Kinnunen, J. (unpublished). Technological Pedagogical Content Design (TPCD) for User-Centered Website: A User Experience Case Study in Finland (in publishing).

Hussien, H. M., Yasin, S. M., Udzir, N. I., Ninggal, M. I. H., \& Salman, S. (2021). Blockchain technology in the healthcare industry: Trends and opportunities. Journal of Industrial Information Integration, 22, 100217.

Hyndman, B. (2018). Ten reasons why teachers can struggle to use technology in the classroom. Science Education News, 67(4), 41-42.

Ionescu, C. A., Paschia, L., Gudanescu Nicolau, N. L., Stanescu, S. G., Neacsu Stancescu, V. M., Coman, M. D., \& Uzlau, M. C. (2020). Sustainability Analysis of the E-Learning Education System during Pandemic Period-COVID-19 in Romania. Sustainability, 12(21), 9030, 22 pp. Retrieved April 27, 2021, from: https://www.mdpi.com/2071-1050/12/21/9030

Jena, P. K. (2020). Impact of pandemic COVID-19 on education in India. International Journal of Current Research (IJCR), 12(7), 12582-12586.

Kinnunen, J., Georgescu, I, (2020). Disruptive Pandemic as a Driver towards Digital Coaching in OECD Countries. Revista Romaneasca pentru Educatie Multidimensionala 12(2 Sup 1), 55-61. doi:10.18662/rrem/12.2Sup $1 / 289$

Mishra, P., \& Koehler, M. J. (2006). Technological pedagogical content knowledge: A framework for teacher knowledge. Teachers College Record, 108(6), 1017-1054.

Mtebe, J. S. (2019). Examining user experience of eLearning systems implemented in two universities in Tanzania. Interactive Technology and Smart Education, 17(1), 39-55. doi:10.1108/ITSE-05-20190025

Nomani, M. Z. M., \& Hussain, Z. (2020). Innovation technology in health care management in the context of Indian environmental planning and sustainable development. International journal on emerging technologies, 11(2), 560-564.

Onyema, E. M., Eucheria, N. C., Obafemi, F. A., Sen, S., Atonye, F. G., Sharma, A., \& Alsayed, A. O. (2020). Impact of Coronavirus pandemic on education. Journal of Education and Practice, 11(13), $108-121$

Roggema, R. (2017). Research by design: Proposition for a methodological approach. Urban science, 1(1), 2, 19 pp.

Semerádová, T., \& Weinlich, P. (2020). Factors Influencing User Experience. In Semerádová, T., \& Weinlich, P, Website Quality and Shopping Behavior (pp. 29-62). Cham: Springer.

Shirley, M. A. J. (2018) Issues and Barriers of Integrating Technology in Education. Special Issue Published in International Journal of Trend in Research and Development (IJTRD), pp 32-35. Retrieved April 27, 2021, from: http://www.ijtrd.com/papers/IJTRD15933.pdf

Singh, R. P., Javaid, M., Haleem, A., \& Suman, R. (2020). Internet of things (IoT) applications to fight against COVID-19 pandemic. Diabetes \& Metabolic Syndrome: Clinical Research \& Reviews, 14(4), 521-524.

Sintawati, M., \& Abdurrahman, G. (2020). The effectiveness of blended learning to improve pre-service teacher TPaCK in developing multimedia learning mathematics at elementary school. Journal of Physics: Conference Series, 1521, 032014, 6 pp.

Ting, D. S. W., Carin, L., Dzau, V., \& Wong, T. Y. (2020). Digital technology and COVID-19. Nature medicine, 26(4), 459-461.

Wijaya, T. T., Tang, J., \& Purnama, A. (2020). Developing an interactive mathematical learning media based on the tpack framework using the hawgent dynamic mathematics software. In Miraz M.H., Excell P.S., Ware A., Soomro S., \& Ali M. (Eds.) International Conference for Emerging Technologies in Computing (pp. 318-328). Cham: Springer, Cham. doi:10.1007/978-3-030-600365_24 